https://doi.org/10.31426/ijamsr.2018.1.10.1017

\title{
Prioritization of Sub-Watersheds of a Western Himalayan Catchment Employing Morphological Derived Compound Index and Sediment Production Rate
}

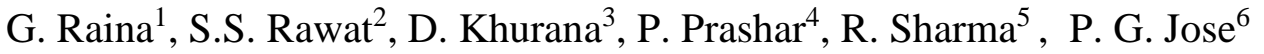 \\ 1,4\&5 University of Jammu, Jammu, Jammu \& Kashmir, India \\ 2,3\&6 Western Himalayan Regional Centre, National Institute of Hydrology, Jammu, \\ Jammu \& Kashmir, India
}

Keywords: GIS, Morphological parameters, Prioritization of watersheds, Sediment production rate

\begin{abstract}
A B S T R A C T
In the present paper, various morphological parameters representing one dimensional view via linear, two dimensional view via a real and three dimensional view via relief aspect of the catchment have been extracted in GIS environment by partitioning a Western Himalayan catchment from the Indian subcontinent into eight sub-watersheds (SW1 to SW8). The study catchment was found to be a sixth order drainage basin as per the Strahler stream ordering scheme. The catchment is dominated by the parallel and dendritic drainage patterns in different sub-watersheds. Higher bifurcation ratios between the first and second order streams imply the presence of active gullies in the catchment. Medium to high drainage densities, ranging 2.64 to 4.08 were found in the study area indicating the weak or impermeable subsurface material, high mountainous relief and fine drainage texture. Most of the sub-watersheds are characterized with high relief ratio, relative relief and average slope which are favorable to generate significant runoff even for a small volume of rainfall. In order to prioritize the catchment, a compound index was calculated by considering the individual rank assigned to all eight sub-watersheds based on 13 morphological parameters. To decide the quantum of conservation work required in each sub-watershed, the quantitative assessment of soil loss has been done using sediment production rate (SPR). Sediment production rate (SPR) of all sub-watersheds varies between $1.18 \mathrm{ha}-\mathrm{m} / 100 \mathrm{sq} . \mathrm{km} / \mathrm{yr}$ to $3.96 \mathrm{ha}-\mathrm{m} / \mathrm{l} 00$ sq.km/yr. These values are in concurrence with the design SPR values as adopted in most of the river valley projects constructed in the Western Himalayan region of India. SPR values estimated as well as compound ranking evaluated using morphological parameters in the present study may be helpful in identifying the critical areas in a ungauged catchment and accordingly deciding the watershed treatment measures in volume and space.
\end{abstract}

Citation: G. Raina, S.S. Rawat, D. Khurana, P. Prashar, R. Sharma, P. G. Jose (2018). Prioritization of Sub-Watersheds of a Western Himalayan Catchment Employing Morphological Derived Compound Index and Sediment Production Rate. International Journal of Advanced Multidisciplinary Scientific Research (IJAMSR ) ISSN:2581-4281 Vol 1, Issue 10, December, 2018, \#Art.1017, pp $55-68$ 


\section{International Journal of Advanced Multidisciplinary Scientific Research (IJAMSR) ISSN:2581-4281}

\section{Introduction}

Watershed planning and management schemes play a vital role in ensuring efficient use of land and water resources in terms of quantity and quality to meet the present and future demands for the stakeholder. The response to soil and water conservation measures for alleviating erosion would be different for different parts of a catchment due to their physiographical variability throughout the catchment or in other words exhibit different physiographical settings in the sub-watersheds of the same catchment. Thus, it is not only necessary to know the state of erosion of the watershed, but it is equally important to quantify the rate of erosion within the watershed to proportionately allocate the funds for their treatment for achieving the best output. In developing countries like India, observations of discharge and suspended sediment yield are usually gauged only at the outlet of large watersheds normally when these rivers enter the plain areas. However, the major sources of sediment are the upstream hilly areas and eroded soils from these areas are transported through small mountainous tributaries, unfortunately, which are un-gauged. The process of soil loss from a watershed is exclusively influenced by erosion, deposition and transportation sub-processes that continuously occur along the sediment flow path within the watershed (Merritt et al. 2003; Aksoy and Kavvas 2005; Rawat et al. 2016). Therefore, using sediment data from the outlet of a large watershed to identify the actual source areas of sediment within the watershed cannot be justified. To overcome this problem, various morphometric parameters (drainage density, drainage frequency, form factor, length of overland flow, elongation ratio, circularity ratio, compactness coefficient, drainage texture, bifurcation ratio, etc.) have been correlated with surface and sub-surface features like slope, soil, rock resistance, structure and geological history of the watershed which are responsible for runoff and consequent erosion of the watershed. These morphometric parameters have been linked with hydrological behavior of an ungauged watershed through popular GIUH theory,(Rodriguez-Iturbeet al., 1979; Gupta et al., 1980), stream profile analysis (Hack, 1973), prioritization of sub-watersheds for their vulnerability of soil erosion (Mishra, 1980; Goel, 2003; Nookaratnam et al., 2005; Jaiswal et al., 2015; Grauso et al., 2008), estimation of sediment production rate (Jose and Das, 1982; Suresh et al., 2004; Grauso et al., 2008; Rymbai and Jha, 2012; Ahmed and Rao, 2015 ), identification of artificial recharge locations (Ghayoumian et al., 2005; Saraf and Chaudhary, 1998; Ghayoumian et al., 2005), permeability of underlying geological formation (Pakhmode et al., 2003; Anbazhagan et al., 2005) and many more.

Since, most of the morphometric parameters are in the form of ratio, scale does not limit their application while comparing for different watersheds. Due to lack of observed data, these morphometric approaches are very popular in characterization of sub-watersheds in reference to their strong relationships with the factors responsible for soil erosion and transportation. Manual estimation of geomorphologic parameters is a tedious and cumbersome process and often discourages the field engineers from developing regional methodologies for solving various hydrological problems of un-gauged catchments or in limited data situations (Singh 1998; Kumar et al. 2001; Singh et al. 2003). With the advancement in the field of geo-spatial technologies like GIS and Remote Sensing (RS), geomorphological 


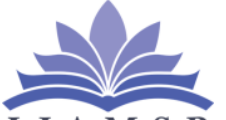

I J A M S R

International Journal of

Advanced Multidisciplinary Scientific Research (IJAMSR) ISSN:2581-4281

parameters can easily be extracted from the digitalized toposheets (Tarboton et al. 1991; Moore et al. 1992; Maathuis 2005; Hengl et al. 2006; Nookaratnam et al. 2005). Moreover, GIS tools are capable of handling spatial and temporal data, with the result that morphometric parameters can be updated whenever any change occurs (Apaydin et al. 2006).

Therefore, considering the strong interaction between the morphology and hydrologic response of the watershed, in the present study morphological characterization of eight sub-watersheds of Ujh catchment has been done using geospatial technique. The prioritization of sub-watersheds has been done through the compound index based on morphometric parameters. The sediment production rates (SPR) from different sub-watersheds have also been estimated using morphological parameters to help in deciding the amplitude of the treatment activities in different areas or sub-watersheds of Ujh catchment.

\subsection{Study Area}

In the present study Ujh river catchment located in district Kathua of Jammu and Kashmir State of India (Fig. 1) is selected for detail morphometric analysis. The Ujh catchment situated between 32.52 to $32.86 \mathrm{~N}$ latitude and 75.37 to $75.75 \mathrm{E}$ longitudes. The river rises from the Domal Structure of Seojdhar of middle Himalayan ranges and the head waters of the river lie in the Kailash Mountains at an altitude of $4300 \mathrm{~m}$ near the Bhaderwah hill of Jammu province. River Ujh flows for a distance of nearly $100 \mathrm{~km}$ before it joins Ravi below Nainkot in West Pakistan. The water of Ujh River is mainly utilized for drinking purposes besides this the River also feeds a number of small canals and Khuls for irrigating the agriculture land of the district. The catchment is hilly, mountainous and rugged, and sloping towards the south from the northern hilly terrain varying in altitude from $510 \mathrm{~m}$ to $4300 \mathrm{~m}$. Areas having an altitude of $2000 \mathrm{~m}$ and above which constitute about $20 \%$ of the catchment are generally snow bound for most of the winter. The climatic conditions of the catchment vary from semi-arid to humid from south to north. The summer temperature rises as high as $48{ }^{\circ} \mathrm{C}$ in the plains and winter temperature in the upper hilly areas touches sub-zero. The mean annual temperature of the southern part of the catchment is $23{ }^{\circ} \mathrm{C}$ and that of the eastern portion of the catchment is $16{ }^{0} \mathrm{C}$. The District experiences rainfall during winter and early summer primarily from western disturbances and monsoon rains from second week of July onwards. The annual rainfall in the entire district is about $1672 \mathrm{~mm}$. About $85 \%$ of the total rainfall is received during monsoon season viz. July to September and rest occurs during December to February.

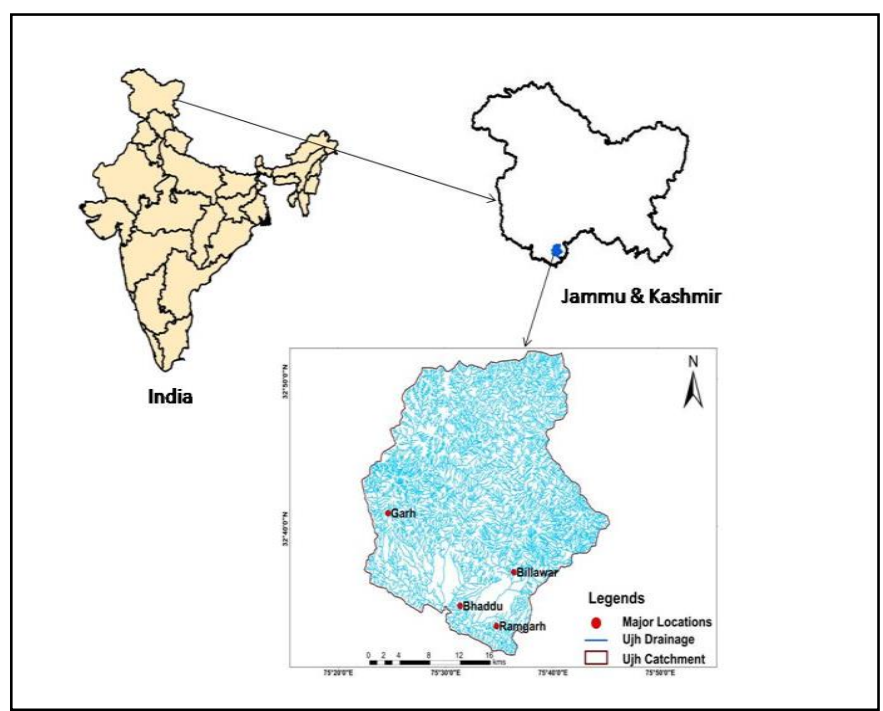

Figure 1: Location map of the Ujh catchment 


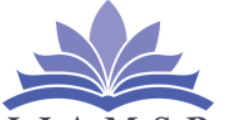

I J A M S R

International Journal of Advanced Multidisciplinary Scientific Research (IJAMSR) ISSN:2581-4281

\subsection{Material and Methods}

\subsection{Data sources and analysis}

In the present study, Ujh River catchment and its drainage network has been delineated from available Survey of India (SOI) topographic maps in the scale of 1:50000 and the attributes were assigned to create the digital database. The topographic maps were first Georeferenced in ArcMap 10.3 software followed by digitization of drainage network. By following the Strahler (1964) method, stream ordering has been carried-out for the entire Ujh catchment and it was found to be sixth order catchment. According to the extracted drainage network, entire drainage area of 867.27 sq. km was subdivided into eight sub-watersheds (Fig. 2), having areas ranging from 30 sq. km (SW6) to 207 sq. $\mathrm{km}$ (SW1) for better understanding with morphometric parameters and finding their correlation with hydrological response and consequence soil erosion of the catchment. The drainage networks of eight different sub-watersheds were analyzed as per Horton's (1945) laws in ArcHydro module of ArcGIS. All subwatersheds have been examined from all dimensional aspects i.e., linear aspect indicates one dimensional view of the watershed, aerial aspect shows two dimensional, however, relief aspect explored three dimensional characteristics of the watersheds. Linear aspect comprises the study of stream order $\left(\mathrm{N}_{\mathrm{u}}\right)$, stream length $(\mathrm{L})$, and bifurcation ratio $\left(\mathrm{R}_{\mathrm{b}}\right)$ whereas aerial aspect deals with drainage density $\left(D_{d}\right)$,stream frequency $\left(F_{s}\right)$, texture $(T)$, form factor $\left(R_{f}\right)$, circulatory ratio $\left(R_{c}\right)$, elongation ratio $\left(\mathrm{R}_{\mathrm{e}}\right)$, compactness coefficient $\left(\mathrm{C}_{\mathrm{c}}\right)$ and length of overland flow $\left(\mathrm{L}_{\mathrm{o}}\right)$, however, total relief $(\mathrm{H})$, relative relief $\left(R_{r}\right)$, relief ratio $\left(R_{0}\right)$ and average slope $\left(S_{a}\right)$ was explored under the relief aspect of Ujh catchment. The formulae for computation of the morphometric parameters are shown in Table 1.

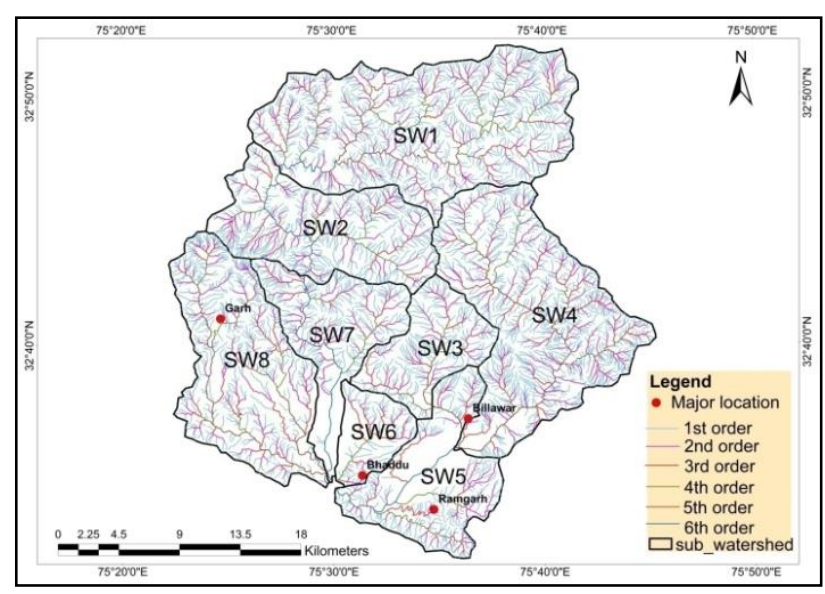

Figure 2. Delineated sub-watersheds of Ujh catchment and their drainage network according to stream order.

All thirteen morphological parameters pertaining to the one, two and three dimensional views of the watershed have been calculated for each sub-watershed of Ujh catchment. Keeping in view the nature of relationships (direct/inverse) of different morphological parameters with erodibility, each sub-watershed has been ranked 1 to 8 based upon thirteen morphological parameters. Rank 1 indicates most severe, whereas 8 denotes least severe with respect to soil erosion. Final prioritization was worked out by considering all ranks of a particular sub-watershed, which were assigned on the basis of thirteen geomorphological parameters considered in the study. The sub-watershed having lowest compound index value has given highest severity towards soil erosion and vice-versa. 
https://doi.org/10.31426/ijamsr.2018.1.10.1017

\section{International Journal of Advanced Multidisciplinary Scientific Research (IJAMSR) ISSN:2581-4281}

Table 1: Different morphometric parameters used in the Study and their standard formulae.

\begin{tabular}{|c|c|c|c|}
\hline & $\begin{array}{l}\text { Morphometric } \\
\text { Parameter }\end{array}$ & Formula & Reference \\
\hline & Stream order(u) & Hierarchical rank & Strahler(1964) \\
\hline & Basin Length(L) & $\begin{array}{l}\mathrm{L}=1.312 * \mathrm{~A}^{0.568} \\
\text { Where } \mathrm{L}=\text { Basin } \\
\text { length }(\mathrm{km}), \\
\mathrm{A}=\text { Area of the } \\
\text { basin }\left(\mathrm{km}^{2}\right)\end{array}$ & $\begin{array}{l}\text { Nookaratnam et } \\
\text { al.(2005) }\end{array}$ \\
\hline & Stream length $\left(\mathrm{L}_{\mathrm{u}}\right)$ & $\begin{array}{l}\text { Length of the } \\
\text { stream }\end{array}$ & Horton (1945) \\
\hline & $\begin{array}{l}\text { Mean stream } \\
\text { length }\left(L_{s m}\right)\end{array}$ & $\begin{array}{l}\mathrm{L}_{\mathrm{sm}}=\mathrm{Lu} / \mathrm{Nu}_{\mathrm{u}} \\
\text { Where } \mathrm{L}_{\mathrm{sm}}=\text { Mean } \\
\text { stream length } \\
\mathrm{L}_{\mathrm{u}}=\text { Total stream } \\
\text { length of order ' } \mathrm{u} \text { ', } \\
\mathrm{Nu}_{\mathrm{u}} \text { Total no. of } \\
\text { stream segments of } \\
\text { order ' } \mathrm{u} \text { ' }\end{array}$ & Strahler (1964) \\
\hline & $\begin{array}{l}\text { Bifurcation ratio } \\
(\mathrm{Rb})\end{array}$ & $\begin{array}{l}\mathrm{Rb}=\mathrm{Nu} / \mathrm{Nu}+1 \\
\text { Where, } \\
\mathrm{R}_{b}=\mathrm{Bifurcation} \\
\text { ratio } \mathrm{Nu}=\text { Total no. } \\
\text { of stream segments } \\
\text { of order ' } \mathrm{u} \text { ', } \\
\mathrm{N}_{\mathrm{u}+1=\text { Number of }} \\
\text { segments of the } \\
\text { next higher order }\end{array}$ & $\begin{array}{l}\text { Schumm } \\
\text { (1956) }\end{array}$ \\
\hline : & $\begin{array}{l}\text { Mean bifurcation } \\
\text { ration }\left(\mathrm{Rbm}_{\mathrm{bm}}\right.\end{array}$ & $\begin{array}{l}\mathrm{Rbm}=\text { Average } \\
\text { of bifurcation } \\
\text { rations of all } \\
\text { orders }\end{array}$ & Strahler(1957) \\
\hline & $\begin{array}{l}\text { Drainage density } \\
\left(D_{d}\right)\end{array}$ & $\begin{array}{lr}\mathrm{D}_{\mathrm{d}}=\mathrm{Lu} / \mathrm{A} & \text { where, } \\
\mathrm{D}_{\mathrm{d}}= & \text { drainage } \\
\text { density, } & \mathrm{Lu}=\text { total } \\
\text { stream } & \text { length of } \\
\text { all, } \mathrm{A}=\text { Area of the } \\
\text { basin }\end{array}$ & Horton(1945) \\
\hline $\bar{\Xi}$ & Form factor $\left(R_{f}\right)$ & $\begin{array}{l}\mathrm{Ff}=\mathrm{A} / \mathrm{L}^{2} \\
\text { Where } \mathrm{Ff}=\mathrm{Form} \\
\text { factor } \mathrm{A}=\mathrm{Area} \text { of } \\
\text { the basin }\left(\mathrm{km}^{2}\right) \text {, } \\
\mathrm{L}=\operatorname{Basin} \\
\text { length }(\mathrm{km})\end{array}$ & $\begin{array}{c}\text { Horton(1932, } \\
1945)\end{array}$ \\
\hline & $\begin{array}{l}\text { Stream frequency } \\
\left(\mathrm{F}_{\mathrm{s}}\right)\end{array}$ & $\begin{array}{l}\mathrm{F}_{\mathrm{s}}=\mathrm{N}_{\mathrm{u}} / \mathrm{A} \\
\mathrm{F}_{\mathrm{s}}=\text { stream } \\
\text { frequency, } \mathrm{N}_{\mathrm{u}}=\text { total } \\
\text { no. of streams of } \\
\text { all orders, } \mathrm{A}=\text { area } \\
\text { of the basin }\end{array}$ & Horton(1945) \\
\hline
\end{tabular}

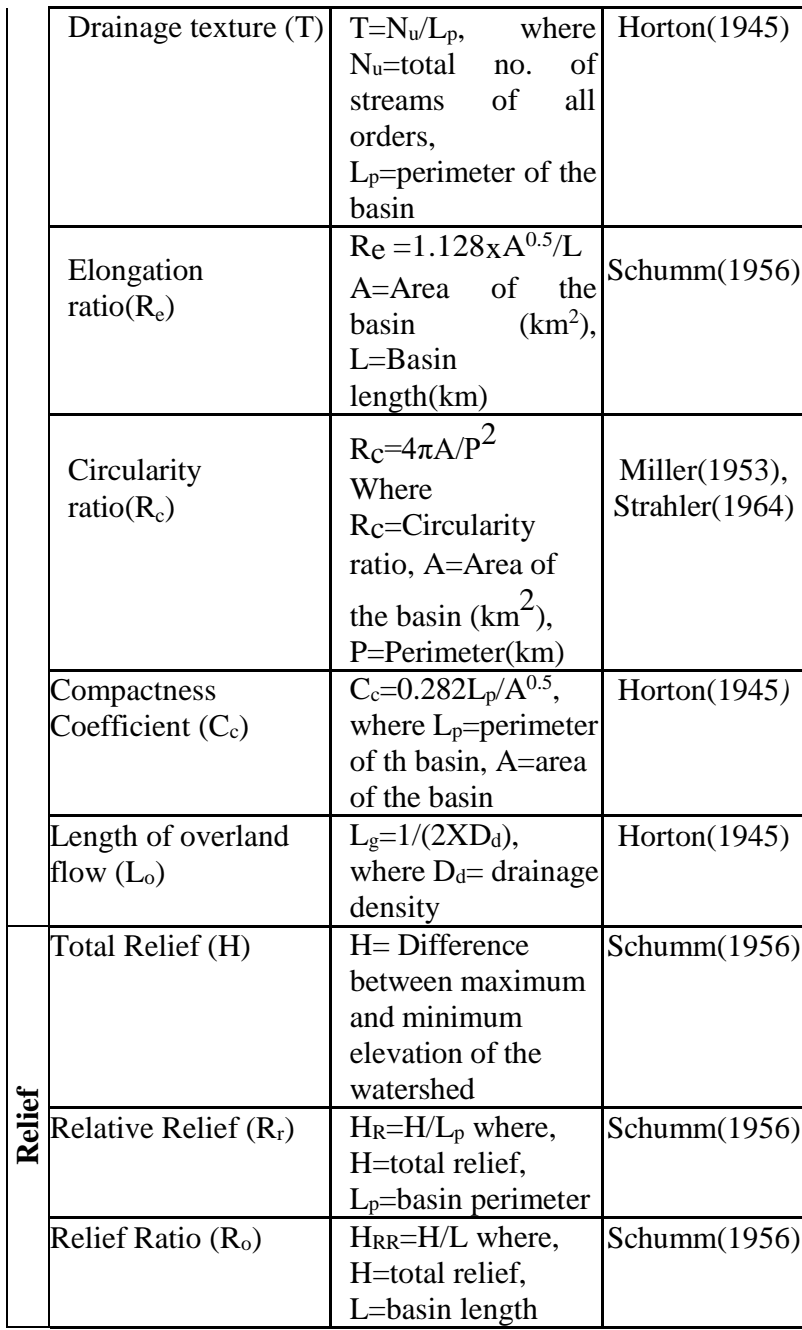

\subsection{Estimation of sediment production rate (SPR)}

Prioritization discussed in the preceding section is only a qualitative representation of soil erosion severity problem faced by each sub-watershed. However, for planning the amplitude of conservation activities in any watershed, quantitative assessment of soil erosion from the area is indispensable. In the view of non-availability of observed data in the un-gauged watersheds/catchments, the actual estimation of soil erosion is almost impossible using traditional modeling approach. However, in such circumstances an alternative approach using Sediment Production Rate (SPR), which 


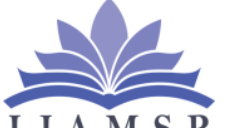

\section{International Journal of Advanced Multidisciplinary Scientific Research (IJAMSR) ISSN:2581-4281}

is the volume of sediment produced per unit watershed area per unit time, can be implemented to provide quantitative assessment of soil erosion. SPR is normally used in designing of the dead storage of a reservoir and hence imperative to decide the life of the reservoir. Morphological based approach for estimation of probable SPR from a watershed may be preferred in absence of observed sediment data. In the present study, the sediment production rate of different sub-watersheds of Ujh River catchment have been estimated by morphological method suggested by Jose and Das (1982) and is expressed by the following equation:

$\log (\mathrm{SPR})=4919.80+48.64 \log \left(100+\mathrm{R}_{\mathrm{t}}\right)-1337.77 \log$ $\left(100+R_{c}\right)-1165.64 \log (100+C c) \ldots(1)$

where, SPR is sediment production rate in ha-m/100 sq. $\mathrm{km}$./year, $\mathrm{R}_{\mathrm{t}}$ is rotundity factor, $\mathrm{R}_{\mathrm{c}}$ is circulatory ratio and $\mathrm{Cc}$ is compactness coefficient.

\subsection{Results and Discussion}

The various morphometric parameters of the $\mathrm{Ujh}$ river catchment in the present study are summarized in Tables 2 to 5 . The basic parameters of all the sub-watersheds of Ujh catchment are shown in Table 2 and other parameters pertaining to linear aspects, areal aspects and relief aspects are described in subsequent sections.
Table 2. Basic Parameters of different subwatersheds of Ujh River Catchment.

\begin{tabular}{|c|c|c|c|}
\hline $\begin{array}{c}\text { SW } \\
\text { Name }\end{array}$ & $\begin{array}{c}\text { Basin } \\
\text { Area }\left(\mathbf{k m}^{2}\right)\end{array}$ & $\begin{array}{c}\text { Perimeter( } \\
\mathbf{k m})\end{array}$ & $\begin{array}{c}\text { Basin } \\
\text { Length(km) }\end{array}$ \\
\hline SW1 & 207.4 & 69.36 & 34.72 \\
\hline SW2 & 105.7 & 51.3 & 13.76 \\
\hline SW3 & 56.16 & 35.16 & 11.44 \\
\hline SW4 & 176.9 & 67.87 & 34.26 \\
\hline SW5 & 84.78 & 50.16 & 16.16 \\
\hline SW6 & 30.42 & 23.71 & 9.16 \\
\hline SW7 & 74.49 & 52.56 & 23.73 \\
\hline SW8 & 131.5 & 57.09 & 27.9 \\
\hline
\end{tabular}

\subsection{Linear aspects}

\section{Stream ordering}

Stream ordering is the first step to extract the geomorphological parameters of a catchment. Ujh River basin was adjudged sixth order basin according to the Strahler (1964) hierarchical rank. The drainage map with stream order of the Ujh catchment is shown in Figure 2. As the stream order increases the total number of streams decreases as suggested by Strahler (1957) and shown in Table 3. The drainage pattern of an area reflects the nature of slope, geological structure and lithologic controls of the underlying rocks (Zernitz, 1932 and Easterbrook, 1969, Nag and Chakraborty, 2003).Ujh catchment comprises of two types of drainage pattern i.e parallel and dendritic. . In parallel drainage system primary and secondary streams flow parallel to each other and meet the main channel at about same angle. Such drainage pattern are pertaining the regional slope and normally start from the water divide of the 
https://doi.org/10.31426/ijamsr.2018.1.10.1017

\section{International Journal of Advanced Multidisciplinary Scientific Research (IJAMSR) ISSN:2581-4281}

watershed. In SW1, SW3, SW6 and SW7 subwatersheds parallel drainage pattern is the dominant drainage pattern. However, dendritic drainage pattern is found frequently in SW2 and SW4 sub-watersheds and some parts of other sub-watersheds also. Dendritic type of drainage pattern refers to the homogeneity in texture, rock and lack of structural control.

Table 3: Extracted stream of different orders and their bifurcation ratios

\begin{tabular}{|c|c|c|c|c|c|c|c|c|}
\hline \multirow[t]{2}{*}{$\begin{array}{l}\text { Sub } \\
- \\
\text { wat } \\
\text { ersh } \\
\text { ed }\end{array}$} & \multirow{2}{*}{$\begin{array}{c}\text { Parame } \\
\text { ter }\end{array}$} & \multicolumn{6}{|c|}{ Stream Order } & \multirow{2}{*}{$\begin{array}{l}\text { Mea } \\
\text { n } \\
\text { Bifu } \\
\text { rcati } \\
\text { on } \\
\text { ratio } \\
\left(\mathbf{R}_{\mathbf{b}}\right)\end{array}$} \\
\hline & & I & II & $\begin{array}{c}\text { II } \\
\text { I }\end{array}$ & $\begin{array}{l}\mathbf{I} \\
\mathbf{V}\end{array}$ & $\mathbf{V}$ & $\begin{array}{l}\mathbf{V} \\
\mathbf{I}\end{array}$ & \\
\hline \multirow{6}{*}{$\begin{array}{c}\text { SW } \\
1\end{array}$} & No. of & 10 & 20 & & & & & \multirow[t]{6}{*}{4.28} \\
\hline & Stream & 53 & 9 & 49 & 8 & 2 & 1 & \\
\hline & Stream & 51 & 12 & 70 & 41 & 22 & & \\
\hline & Length( & 7. & 3. & .4 & .3 & .6 & 6. & \\
\hline & $\mathrm{km})$ & 56 & 94 & 1 & 9 & 9 & 63 & \\
\hline & $\begin{array}{l}\text { Bifurcat } \\
\text { ion ratio }\end{array}$ & $\begin{array}{l}5 . \\
04\end{array}$ & $\begin{array}{l}4 . \\
26\end{array}$ & $\begin{array}{l}6 . \\
12\end{array}$ & $\begin{array}{l}4 . \\
00\end{array}$ & 2 & - & \\
\hline \multirow{6}{*}{$\begin{array}{c}\text { SW } \\
2\end{array}$} & No. of & 50 & & & & & & \multirow[t]{6}{*}{4.02} \\
\hline & Stream & 0 & 96 & 26 & 5 & 1 & 1 & \\
\hline & Stream & 27 & 70 & 31 & 14 & & & \\
\hline & Length( & 2. & .9 & .4 & .7 & 3. & 11 & \\
\hline & $\mathrm{km})$ & 59 & 9 & 1 & 1 & 33 & .9 & \\
\hline & $\begin{array}{l}\text { Bifurcat } \\
\text { ion ratio }\end{array}$ & $\begin{array}{l}5 . \\
21\end{array}$ & $\begin{array}{l}3 . \\
69\end{array}$ & $\begin{array}{l}5 . \\
2\end{array}$ & 5 & 1 & - & \\
\hline \multirow{6}{*}{$\begin{array}{c}\text { SW } \\
\mathbf{3}\end{array}$} & No. of & 20 & & & & & & \multirow[t]{6}{*}{3.89} \\
\hline & Stream & 4 & 47 & 9 & 3 & 1 & - & \\
\hline & Stream & 13 & 32 & 16 & & & & \\
\hline & Length( & 5. & .2 & .5 & 8. & 4. & & \\
\hline & $\mathrm{km})$ & 71 & 0 & 8 & 09 & 46 & - & \\
\hline & $\begin{array}{l}\text { Bifurcat } \\
\text { ion ratio }\end{array}$ & $\begin{array}{l}4 . \\
34\end{array}$ & $\begin{array}{l}5 . \\
22\end{array}$ & $\begin{array}{l}3 . \\
00\end{array}$ & $\begin{array}{l}3 . \\
00\end{array}$ & - & - & \\
\hline \multirow{6}{*}{$\begin{array}{c}\text { SW } \\
4\end{array}$} & No. of & 88 & 18 & & & & & \multirow[t]{6}{*}{3.51} \\
\hline & Stream & 0 & 7 & 40 & 8 & 3 & 1 & \\
\hline & Stream & 49 & 11 & 60 & 25 & 28 & & \\
\hline & Length( & 2. & 4. & .6 & .6 & .8 & 0. & \\
\hline & $\mathrm{km})$ & 04 & 24 & 3 & 2 & 0 & 38 & \\
\hline & $\begin{array}{l}\text { Bifurcat } \\
\text { ion ratio }\end{array}$ & $\begin{array}{l}4 . \\
71\end{array}$ & $\begin{array}{l}4 . \\
68\end{array}$ & $\begin{array}{l}5 . \\
00\end{array}$ & $\begin{array}{l}2 . \\
67\end{array}$ & $\begin{array}{l}3 . \\
00\end{array}$ & $\begin{array}{l}1 . \\
00\end{array}$ & \\
\hline SW & No. of & 26 & 62 & 15 & 3 & 1 & 1 & 3.49 \\
\hline
\end{tabular}

\begin{tabular}{|c|c|c|c|c|c|c|c|c|}
\hline \multirow[t]{5}{*}{5} & Stream & 7 & & & & & & \\
\hline & Stream & 14 & 42 & 24 & 14 & & 12 & \\
\hline & Length( & 5. & .4 & .8 & .7 & 3. & .1 & \\
\hline & $\mathrm{km})$ & 87 & 6 & 0 & 6 & 26 & 5 & \\
\hline & $\begin{array}{l}\text { Bifurcat } \\
\text { ion ratio }\end{array}$ & $\begin{array}{l}4 . \\
31\end{array}$ & $\begin{array}{l}4 . \\
13\end{array}$ & $\begin{array}{l}5 . \\
00\end{array}$ & $\begin{array}{l}3 . \\
00\end{array}$ & $\begin{array}{l}1 . \\
00\end{array}$ & - & \\
\hline \multirow[t]{5}{*}{$\begin{array}{c}\text { SW } \\
6\end{array}$} & $\begin{array}{l}\text { No. of } \\
\text { Stream }\end{array}$ & 90 & 21 & 7 & 1 & - & - & \multirow[t]{5}{*}{4.76} \\
\hline & Stream & 49 & 12 & 12 & & & & \\
\hline & Length( & .2 & .1 & .8 & 6. & & & \\
\hline & $\mathrm{km})$ & 10 & 8 & 3 & 15 & - & - & \\
\hline & $\begin{array}{l}\text { Bifurcat } \\
\text { ion ratio }\end{array}$ & $\begin{array}{l}4 . \\
28\end{array}$ & $\begin{array}{l}3 . \\
00\end{array}$ & $\begin{array}{c}7 . \\
00\end{array}$ & - & - & - & \\
\hline \multirow{7}{*}{$\begin{array}{c}\text { SW } \\
7\end{array}$} & No. of & 26 & & & & & & \multirow[t]{7}{*}{3.75} \\
\hline & Stream & 8 & 58 & 14 & 2 & 1 & 1 & \\
\hline & Stream & 15 & 41 & 17 & & & 20 & \\
\hline & Length( & 3. & .1 & .3 & 7. & 0. & .0 & \\
\hline & $\mathrm{km})$ & 76 & 1 & 5 & 22 & 11 & 5 & \\
\hline & Bifurcat & 4. & 4. & 7. & 2. & 1. & & \\
\hline & ion ratio & 62 & 14 & 00 & 00 & 00 & - & \\
\hline \multirow{7}{*}{$\begin{array}{c}\text { SW } \\
8 \\
\end{array}$} & No. of & 50 & 11 & & & & & \\
\hline & Stream & 5 & 1 & 29 & 7 & 2 & - & \\
\hline & Stream & 27 & 69 & 42 & 18 & 32 & & \multirow[t]{3}{*}{4.01} \\
\hline & Length( & 9. & .9 & .2 & .7 & .7 & & \\
\hline & $\mathrm{km})$ & 22 & 7 & 5 & 0 & 4 & - & \\
\hline & Bifurcat & 4. & 3. & 4. & 3. & & & \\
\hline & ion ratio & 55 & 83 & 14 & 5 & - & - & \\
\hline
\end{tabular}

\section{Stream Length}

Numbers of stream of various orders in all subwatersheds were counted and their lengths from mouth to drainage divide were measured with the help of GIS software and depicted in Table 3.Generally, the total lengths of stream segments are highest in first order streams and decreases as the stream order increases (Table 3). However, in case of SW1, SW4, and SW8 sub-watersheds the stream segments of first orders are proportionately very high as compare to general observation (Table 3). This change may indicate flowing of streams from high altitude, lithological variation and converging terrain (Singh and Singh, 1997).

Bifurcation Ratio $\left(\boldsymbol{R}_{b}\right)$ 


\section{International Journal of Advanced Multidisciplinary Scientific Research (IJAMSR) ISSN:2581-4281}

Abnormally high value of $R_{b}$ might be expected in region of steeply dipping rock strata. The value of $R_{b}$ is also indicative of shape of the basin. An elongated basin is likely to have high $R_{b}$, where as a circular basin is likely to have a low $\mathrm{R}_{\mathrm{b}}$. In the study area, the values of $\mathrm{R}_{\mathrm{b}}$ are in the middle range and vary from 3.5 to 4.8 (Table 3). The minimum and maximum value was found to be 3.51 and 4.76 for sub-watershed SW4 and SW6, respectively. It can be witnessed from Table 3 , the bifurcation ratios between the first order, second order and third order streams are higher than the other higher orders in all sub micro-watersheds indicating that the catchment falls under areas of active gullies and ravines, hence, higher erosion rates.

\subsection{Areal Aspects}

Areal aspects include different morphometric parameters, like drainage density $\left(D_{d}\right)$, stream frequency $\left(F_{s}\right)$, drainage texture $(T)$, form factor $\left(R_{f}\right)$, infiltration number $(\mathrm{I})$, circulatory ratio $\left(\mathrm{R}_{\mathrm{c}}\right)$, elongation ratio $\left(\mathrm{R}_{\mathrm{e}}\right)$ and length of the overland flow $\left(\mathrm{L}_{0}\right)$ and compactness coefficient $\left(\mathrm{C}_{\mathrm{c}}\right)$. The values of these parameters were calculated and results have been given in Table 4.

\section{Drainage Density $\left(D_{d}\right)$}

Drainage basin with high $D_{d}$ indicates that a large proportion of the precipitation is run-off. The drainage density, expressed in $\mathrm{km} / \mathrm{km}^{2}$, indicates closeness of spacing of channels, thus providing a quantitative measure of the average length of stream channel for the whole basin. Further, it also gives an idea of the physical properties of the underlying rocks. Low drainage density occurs in regions of highly resistant and permeable sub soil materials with dense vegetation and low relief, whereas high drainage density is prevalent in region of weak, impermeable sub-surface material which is sparsely vegetated and has high relief (Strahler1964). Drainage density in the study area varies between 2.64 (SW6) and 4.08 (SW4) indicating medium to high drainage density (Table 4). High drainage density of 4.08 in SW4 sub-watershed may be resultant of weak or impermeable subsurface material, high mountainous relief and fine drainage texture. However, low drainage density in SW6, SW5 and SW2 sub-watersheds indicate areas of highly resistant on permeable subsoil material, low relief and coarse drainage texture.

\section{Stream Frequency /Drainage Frequency $\left(F_{s}\right)$}

It mainly depends upon the lithology of the basin and reflects the texture of the drainage network. Stream frequency of Ujh sub-watersheds varies from 3.91 to 6.37. Sub-watershed SW1, SW2, SW4 and SW8 associated with high stream frequency while subwatersheds SW6 having low stream frequency. Drainage density and stream frequency has a similar measure of stream network of a drainage basin. Table 4 shows close correlation between drainage frequency with drainage density indicating the increase in stream population with respect to increase in drainage density.

\section{Drainage Texture $(T)$}

Drainage texture is the ratio of the total number of stream segments of all orders to the perimeter of that area (Horton, 1945). Smith (1939) classified five different categories of $D_{t}$ namely very coarse $(<2)$, coarse (2 to 4 ), moderate (4 to 6 ), fine (6 to 8 ) and very fine (>8).The drainage texture of entire 8 sub-watersheds are of coarse to very fine. The sub-watershed located in the downstream of Ujh catchment (SW5, SW6, SW7, and SW8) consist coarse drainage texture however, sub- 


\section{International Journal of Advanced Multidisciplinary Scientific Research (IJAMSR) ISSN:2581-4281}

watersheds of upstream part or hilly region (SW1, SW3 and SW4), comprise moderate to very fine texture. More finer is the texture more will be dissection and leads more erosion.

\section{Form Factor $\left(\boldsymbol{R}_{f}\right)$}

It is dimensionless property and is used as a quantitative expression of the shape of basin form. The values of form factor of the sub-watersheds in the present case are in between 0.13-0.56. According to form factor SW1, SW4, SW7 and SW8 are relatively more elongated due to low values of form factor. However, SW2, SW3, SW5 and SW6 are relatively having high values of form factor and hence less elongated. The basins with high form factors, have high peak flows of shorter duration, whereas, elongated drainage basin with low form factors have lower peak flow of longer duration.

\section{Infiltration Number (I)}

The infiltration Number is defined as the product of Drainage Density $\left(D_{d}\right)$ and Drainage Frequency $\left(F_{s}\right)$. Sub-watershed SW6 has the low infiltration 10.34 and the sub-watershed SW4 has the higher infiltration number of 25.81. Higher the infiltration number lower will be infiltration and consequently higher will be run off. It gives an idea about the infiltration characteristics which play vital role in transformation of rainfall into the runoff. High value of infiltration number SW1, SW2 and SW4 reveal that the sub-watersheds are impermeable lithology and higher relief.

\section{Circulatory Ratio $\left(\boldsymbol{R}_{c}\right)$}

The circulatory ratio is a similar measure as elongation ratio, originally defined by Miller (1953), as the ratio of the area of the basin to the area of the circle having same circumference as the basin perimeter. The value of circularity ratio varies from 0 (in line) to 1 (in a circle). The Circulatory ratio for all sub-watersheds is in the range of 0.34 to 0.68 . It is clear from the Fig. 2 that SW7 is elongated and hence attributed to low value of circulatory ratio (0.34), however, SW6 is circularin nature and associated with higher value of circulatory ratio (0.68).

\section{Elongation Ratio $\left(\boldsymbol{R}_{e}\right)$}

It is defined as the ratio between the diameter of a circle with the same area that of the basin to the maximum length of the basin. The elongation ratio ranges from 0.0 to 1.0 over a wide variety of climatic and geological environments. High Value (nearing 1) of elongation ratio is typical of regions of low relief, whereas low values are generally associated with strong relief and steep ground slopes. In Ujh catchment area SW1, SW4, SW7, SW8 are having high relief (consisting high average slope) and hence associated with low values of elongation ratio.

\section{Length of Overland Flow $\left(L_{o}\right)$}

The term length of overland flow is used to describe the length of flow of water over the ground before it becomes concentrated in definite stream channels. Horton (1945) expressed it as equal to half of the reciprocal of drainage density $\left(D_{d}\right)$. This factor relates inversely to the average slope of the channel and is quite synonymous with the length of sheet flow at a large degree. Overland flow lengths are ranging from 122.56 meter to 189.22 meter in Ujh sub-watersheds. SW4 has highest relief among all sub-watersheds and hence has low length of overland flow i.e. 122.56 meter. However, Smaller the value of overland flow the quicker surface 


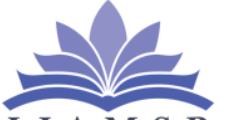

I J A M S R

International Journal of

Advanced Multidisciplinary Scientific Research (IJAMSR) ISSN:2581-4281

runoff will enter the streams represents well developed drainage network with higher slope. In such watersheds a significant amount of surface runoff is to be contributed in the stream discharge for even a low amount of rainfall.

\section{Compactness constant $\left(C_{c}\right)$}

Compactness coefficient is used to express the relationship of a hydrologic basin with that of a circular basin having the same area as the hydrologic basin. A circular basin is the most hazardous from as drainage stand point because it will yield the shortest time of concentration before peak flow occurs in the basin. The values of $\mathrm{C}_{c}$ in the eight sub-watersheds of Ujh catchment varies from 1.21 to 1.72 showing variations across the watersheds. It can be shown from the Fig 2 that SW6 is somewhat circular in shape which tends to low value of compactness coefficient (close to unity). However, SW5 and SW7 having higher values of Cc due to their elongated shape.

Table 4: Aerial Aspect of the Ujh River Catchment

\begin{tabular}{|c|c|c|c|c|c|c|c|c|c|}
\hline $\begin{array}{c}\text { Sub- } \\
\text { Waters } \\
\text { hed }\end{array}$ & $\begin{array}{c}\mathbf{D}_{\mathrm{d}} \\
(\mathbf{k m} / \\
\left.\mathbf{k m}^{2}\right)\end{array}$ & $\begin{array}{c}\mathbf{F}_{\mathrm{s}} \\
(\mathbf{n o .} / \\
\left.\mathbf{k m}^{2}\right)\end{array}$ & $\mathbf{I}$ & $\begin{array}{l}\mathbf{R} \\
\mathrm{c}\end{array}$ & $\begin{array}{c}\mathbf{R} \\
\mathbf{f}\end{array}$ & $\begin{array}{c}\mathbf{R} \\
\mathrm{e}\end{array}$ & $\mathbf{T}$ & $\begin{array}{c}\text { Lo } \\
( \\
\text { m } \\
\text { ) }\end{array}$ & $\begin{array}{l}\mathbf{C} \\
\mathrm{c}\end{array}$ \\
\hline SW1 & 3.77 & 6.37 & $\begin{array}{c}24 \\
0\end{array}$ & $\begin{array}{c}0 . \\
5\end{array}$ & $\begin{array}{c}0 . \\
1\end{array}$ & $\begin{array}{c}0 . \\
4\end{array}$ & $\begin{array}{r}19 \\
0\end{array}$ & $\begin{array}{r}13 \\
25\end{array}$ & $\begin{array}{l}1 . \\
3\end{array}$ \\
\hline SW2 & 3.83 & 5.95 & $\begin{array}{r}22 \\
8\end{array}$ & $\begin{array}{l}0 . \\
5\end{array}$ & $\begin{array}{c}0 . \\
5\end{array}$ & $\begin{array}{l}0 . \\
8\end{array}$ & $\begin{array}{r}12 \\
2\end{array}$ & $\begin{array}{l}13 \\
05\end{array}$ & 1. \\
\hline SW 3 & 3.51 & 4.70 & $\begin{array}{r}16 \\
4\end{array}$ & $\begin{array}{c}0 . \\
5\end{array}$ & 0. & $\begin{array}{l}0 \\
0 . \\
7\end{array}$ & $\begin{array}{r}23 \\
0\end{array}$ & $\begin{array}{r}14 \\
25\end{array}$ & 1. \\
\hline SW4 & 4.08 & 6.33 & $\begin{array}{r}25 \\
8\end{array}$ & $\begin{array}{l}0 . \\
\Delta\end{array}$ & 0. & $\begin{array}{l}0 . \\
1\end{array}$ & $\begin{array}{r}32 \\
6\end{array}$ & $\begin{array}{r}12 \\
25\end{array}$ & 1. \\
\hline SW5 & 2.87 & 4.12 & $\begin{array}{c}11 \\
8\end{array}$ & 0. & 0. & $\begin{array}{l}0 . \\
6\end{array}$ & 6. & $\begin{array}{r}17 \\
12\end{array}$ & 1. \\
\hline SW6 & 2.64 & 3.91 & $\begin{array}{r}10 \\
3\end{array}$ & 0. & $\begin{array}{c}0 . \\
3\end{array}$ & $\begin{array}{c}0 . \\
6\end{array}$ & 5. & $\begin{array}{l}18 \\
02\end{array}$ & 1. \\
\hline SW7 & 3.22 & 4.62 & $\begin{array}{c}14 \\
8\end{array}$ & $\begin{array}{c}0 . \\
3\end{array}$ & $\begin{array}{c}0 . \\
1 \\
\end{array}$ & $\begin{array}{l}0 . \\
1 \\
4\end{array}$ & $\begin{array}{r}6 . \\
54\end{array}$ & $\begin{array}{r}15 \\
54\end{array}$ & $\begin{array}{l}1 . \\
7\end{array}$ \\
\hline SW8 & 3.37 & 4.97 & $\begin{array}{l}16 \\
.7 \\
5\end{array}$ & $\begin{array}{l}0 . \\
5 \\
1\end{array}$ & $\begin{array}{c}0 . \\
1 \\
7\end{array}$ & $\begin{array}{l}0 . \\
4 \\
6\end{array}$ & $\begin{array}{l}11 \\
.4 \\
6\end{array}$ & $\begin{array}{c}14 \\
8.4 \\
6 \\
\end{array}$ & $\begin{array}{l}1 . \\
4 \\
0\end{array}$ \\
\hline
\end{tabular}

\subsection{Relief Aspects}

Relief aspects of drainage basin relate to the three dimensional features of the basin involving area, volume and altitude of vertical dimension of landforms wherein different morphometric methods are used to analyze terrain characteristics. Because many landscape processes are driven by gravity and relief properties are frequently used as indicators of erosion potential and denudation rates. In this study, thus, relief aspect includes the analysis of total relief, relief ratio, relative relief and average slope of all seven sub-watersheds of the Ujh catchment.

\section{Total Relief $(\boldsymbol{H})$}

It is the maximum vertical distance between the lowest and highest point of the watershed. It is also known as maximum watershed relief. Watershed relief controls the gradient of drainage lines within the watershed and hence significantly influences the soil erosion of the watershed (Patton et al., 1988 and Ozdemir and Bird, 2009). SW1 is attributed by high relief i.e. $3164 \mathrm{~m}$ and SW2, SW3, SW4, SW5, SW7 and SW8 comprise medium to high relief i.e. 1809 m, 1514 m, 2623 m 1033 m, $1472 \mathrm{~m}$, and $1667 \mathrm{~m}$ respectively. However, SW6 is attributed to low relief i.e. $425 \mathrm{~m}$. Most of the watersheds are associated with medium to high range relief and hence prone to generation of significant runoff and consequent soil erosion.

\section{Relief Ratio $\left(\boldsymbol{R}_{h}\right)$}

The relief ratio defined as the ratio between the total relief of a basin and the longest dimension of the basin parallel to the main drainage line (Schumm,1956). The advantage of relief ratio over the total watershed relief as it removes the size effect by dividing the total relief by 
the basin length. In Ujh watershed relief ratio varies from $46.397 \mathrm{~m} / \mathrm{km}$ (SW6) to $132.343 \mathrm{~m} / \mathrm{km}$ (SW3)(Table 5). Significant high relief ratio especially in SW3 indicates the steepness of the principal flow path which eventually severally eroded the bank of the stream.

\section{Relative Relief $\left(\boldsymbol{R}_{r}\right)$}

It is the ratio of the maximum watershed relief to the perimeter of the watershed. Relative relief represents actual variation of altitude in a unit area with respect to its local base level. It enumerates that the steeper the slope the higher is the surface above its base. The values of the relative reliefs for 8 Sub-Watersheds of Ujh catchment vary from $17.925 \mathrm{~m} / \mathrm{km} \quad$ (SW6) to $45.617 \mathrm{~m} / \mathrm{km}$ (SW1), indicating the terrain of $\mathrm{Ujh}$ catchment is highly undulating. High values of $R_{r}$ for SW1 and SW3 sub-watershed indicates that these are highly susceptible to soil erosion.

\section{Average Slope $\left(S_{a}\right)$}

Average slope of the watershed, $\mathrm{S}_{\mathrm{a}}$ has direct influence on the erodibility of the watershed. It has been proved by researcher that more the percentage of slopes more are the erosion, if other factors remain unchanged. The average slope for different sub-watersheds varies between $12.379 \%$ (SW6) to $48.126 \%$ (SW1) (Table 5). It was observed that high relief ratio and relative relief sub-watersheds are characterized by high slopes and vice versa.
Table 5. Relief Aspect of the Ujh River Catchment

\begin{tabular}{|c|c|c|c|c|}
\hline & $\mathrm{H}$ & $\mathrm{R}_{\mathrm{h}}$ & $\mathrm{R}_{\mathrm{r}}$ & $\mathrm{S}_{\mathrm{a}}$ \\
\cline { 2 - 5 } Sub-Watershed & $(\mathrm{m})$ & $(\mathrm{m} / \mathrm{km})$ & $(\mathrm{m} / \mathrm{km})$ & $(\%)$ \\
\hline SW1 & 3164 & 91.129 & 45.617 & 48.126 \\
\hline SW2 & 1809 & 131.468 & 35.263 & 40.891 \\
\hline SW 3 & 1514 & 132.343 & 43.060 & 31.945 \\
\hline SW4 & 2623 & 76.562 & 38.647 & 40.586 \\
\hline SW5 & 1033 & 63.923 & 20.594 & 16.013 \\
\hline SW6 & 425 & 46.397 & 17.925 & 12.379 \\
\hline SW7 & 1472 & 62.031 & 28.006 & 33.861 \\
\hline SW8 & 1667 & 59.749 & 29.200 & 23.422 \\
\hline
\end{tabular}

4.4 Prioritization of Sub-watersheds using Morphological Parameters

Morphological parameters (linear, aerial and relief) for all sub-watersheds were calculated separately and shown in Table 2-5. For prioritization, all eight sub-watersheds are ranked based upon their corresponding morphological parameters value. Morphological parameters like drainage density, stream frequency, bifurcation ratio, infiltration number and texture ratio have direct relationship with erosivity. Therefore, the sub-watershed having highest numerical value of these individual parameters was assigned ranked first and next higher was second and so on. Similarly, aerial parameters like elongation ratio, circulatory ratio, form factor and compactness coefficient having the inverse relationship with erosivity. Therefore, the sub-watershed having lowest value of these individual parameters was assigned rank first and next lower was second and so on. Similarly, sub-watersheds are ranked according to relief aspect as it has direct relationship with the erosivity. 


\section{International Journal of Advanced Multidisciplinary Scientific Research (IJAMSR) ISSN:2581-4281}

Finally, based upon all individual ranking, a compound ranking was calculated for each sub-watershed and depicted in Table 6. It is evident from the Table 6 that SW1 has the first priority (lowest value of compound parameter i.e. 3.1) and SW6 has the least priority (highest value of compound parameter i.e. 6.1). The highest priority indicates the greater degree of erosion in the particular sub-watershed and it becomes a potential candidate for applying soil conservation measures. Thus, in order to check soil erosion, treatment has to be started from SW1 and then to others depending on their priority. The priority map of Ujh catchment is shown in Figure 3.

Table 6: Prioritization of Sub-watersheds of Ujh catchment according to morphological parameters.

\begin{tabular}{|c|c|c|c|c|c|c|c|c|c|c|c|c|c|c|c|}
\hline \multirow{2}{*}{$\begin{array}{c}\text { Su } \\
\text { b- } \\
\text { W } \\
\text { ate } \\
\text { rs } \\
\text { he } \\
\text { d } \\
\text { No } \\
\text {. }\end{array}$} & \multicolumn{13}{|c|}{ Morphological Parameter } & \multirow[b]{2}{*}{$\begin{array}{c}\text { Co } \\
\text { mp } \\
\text { ou } \\
\text { nd } \\
\text { Pa } \\
\text { ra } \\
\text { me } \\
\text { ter }\end{array}$} & \multirow[b]{2}{*}{$\begin{array}{c}\mathrm{Fi} \\
\text { na } \\
\text { l } \\
\mathrm{R} \\
\text { an } \\
\text { ki } \\
\text { ng }\end{array}$} \\
\hline & $\begin{array}{l}\mathbf{R} \\
\mathbf{b}\end{array}$ & $\begin{array}{l}\text { D } \\
\text { d }\end{array}$ & $\begin{array}{l}\mathbf{F} \\
\mathrm{s}\end{array}$ & $\mathbf{I}$ & $\begin{array}{l}\mathbf{R} \\
\mathbf{c}\end{array}$ & $\begin{array}{l}\mathbf{R} \\
\mathbf{f}\end{array}$ & $\begin{array}{l}\mathbf{R} \\
\mathrm{e}\end{array}$ & $\mathbf{T}$ & & $\mathbf{H}$ & $\begin{array}{l}\mathbf{R} \\
\mathbf{h}\end{array}$ & $\begin{array}{l}\mathbf{R} \\
\mathbf{r}\end{array}$ & $\begin{array}{l}\mathbf{S} \\
\mathbf{a}\end{array}$ & & \\
\hline $\begin{array}{c}\mathrm{S} \\
\mathrm{W} \\
1 \\
\end{array}$ & 3 & 3 & 8 & 2 & 6 & 3 & 4 & 3 & 3 & 1 & 3 & 1 & 1 & $\begin{array}{c}3.1 \\
53 \\
8 \\
\end{array}$ & 1 \\
\hline $\begin{array}{c}\mathrm{S} \\
\mathrm{W} \\
2\end{array}$ & 4 & 2 & 6 & 3 & 4 & 8 & 8 & 4 & 5 & 3 & 2 & 4 & 2 & $\begin{array}{c}4.2 \\
30 \\
8\end{array}$ & 3 \\
\hline $\begin{array}{c}\mathrm{S} \\
\mathrm{W} \\
3\end{array}$ & 5 & 4 & 4 & 5 & 7 & 7 & 7 & 2 & 2 & 5 & 1 & 2 & 5 & $\begin{array}{c}4.3 \\
07 \\
7\end{array}$ & 4 \\
\hline $\begin{array}{c}\text { S } \\
\text { W } \\
4\end{array}$ & 6 & 1 & 7 & 1 & 3 & 2 & 2 & 1 & 6 & 2 & 4 & 3 & 3 & $\begin{array}{c}3.1 \\
53 \\
8\end{array}$ & 2 \\
\hline $\begin{array}{c}\mathrm{S} \\
\mathrm{W} \\
5 \\
\end{array}$ & 8 & 7 & 2 & 7 & 2 & 5 & 5 & 6 & 7 & 7 & 5 & 7 & 7 & $\begin{array}{c}5.7 \\
69 \\
2 \\
\end{array}$ & 7 \\
\hline $\begin{array}{c}\mathrm{S} \\
\mathrm{W} \\
6\end{array}$ & 1 & 8 & 1 & 8 & 8 & 6 & 6 & 8 & 1 & 8 & 8 & 8 & 8 & $\begin{array}{c}6.0 \\
76 \\
9 \\
\end{array}$ & 8 \\
\hline $\begin{array}{c}\mathrm{S} \\
\mathrm{W} \\
7\end{array}$ & 7 & 6 & 3 & 6 & 1 & 1 & 1 & 7 & 8 & 6 & 6 & 6 & 4 & $\begin{array}{c}4.7 \\
69 \\
2 \\
\end{array}$ & 6 \\
\hline $\begin{array}{c}\mathrm{S} \\
\mathrm{W} \\
8 \\
\end{array}$ & 2 & 5 & 5 & 4 & 5 & 4 & 3 & 5 & 4 & 4 & 7 & 5 & 6 & $\begin{array}{c}4.5 \\
38 \\
5 \\
\end{array}$ & 5 \\
\hline
\end{tabular}

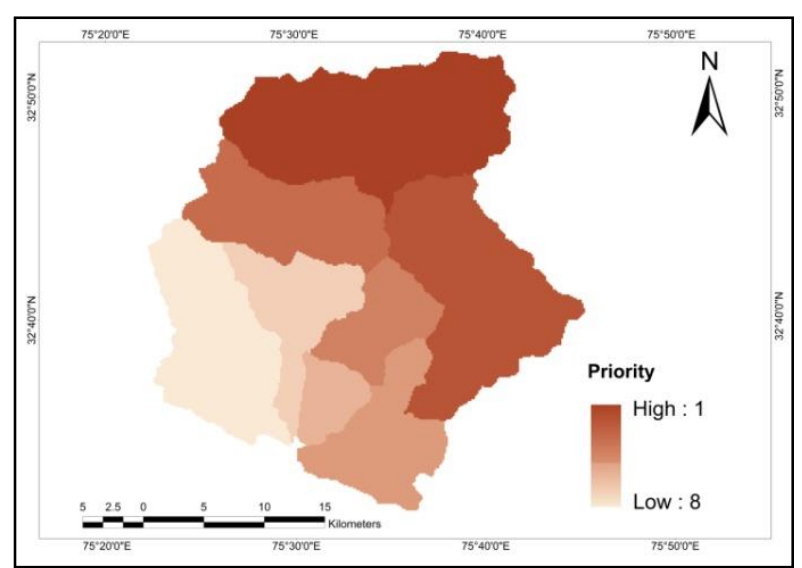

Figure 3: Sub-watershed wise priority map of Ujh catchment.

4.5 Estimation of Sediment Production Rate (SPR) using morphological parameters

Sediment production rate (SPR) for various subwatersheds was estimated using Eq. 1. and tabulated in Table 7. From this analysis, the highest SPR was found to be $3.96 \mathrm{ha}-\mathrm{m} / 100 \mathrm{sq} . \mathrm{km} / \mathrm{yr}$ for SW1, indicates that the watershed produces significant amount of sediment load annually. Estimated SPR value is also close to the design SPR values (4.3 ha-m/100 sq.km/yr) for major river valley projects in Western Himalayan region viz. Beas in Himachal Pradesh, Bhakra-Nangal on Satluj and Ramganga in Uttarakhand. . It was found that the SPRs estimated for different sub-watersheds using Eq.1 have concurrence to the priority as listed in Table 6. Sediment Production Rate (SPR) calculated in this study for an ungauged catchment not only plays a key role in fixing the priority of watershed but it is vital important in deciding the volume of the conservation measures to reduce the SPR at certain level. Moreover, priority classification based on standardized SPR gave a better distribution of sub-watersheds between various priority categories. 


\section{International Journal of Advanced Multidisciplinary Scientific Research (IJAMSR) ISSN:2581-4281}

Table 7: Estimated sediment production rate (SPR) for different sub-watersheds of Ujh catchment.

\begin{tabular}{|c|c|c|c|c|c|c|c|c|}
\hline \multirow{4}{*}{$\begin{array}{c}\text { Particul } \\
\text { ars }\end{array}$} & \multicolumn{7}{|c|}{ Sub-watershed of Ujh catchment } \\
\cline { 2 - 9 } & S & S & S & S & S & S & S & S \\
& W2 & W3 & W4 & W5 & W6 & W7 & \begin{tabular}{l} 
W8 \\
\hline
\end{tabular} \\
\hline SPR & $\begin{array}{c}3.9 \\
6\end{array}$ & $\begin{array}{c}2.2 \\
8\end{array}$ & $\begin{array}{c}2.6 \\
5\end{array}$ & $\begin{array}{c}3.7 \\
9\end{array}$ & $\begin{array}{c}1.7 \\
8\end{array}$ & $\begin{array}{c}2.3 \\
4\end{array}$ & $\begin{array}{c}1.1 \\
8\end{array}$ & $\begin{array}{c}3.7 \\
7\end{array}$ \\
\hline
\end{tabular}

\section{Conclusion}

Prioritization is to be the first and primary step for any watershed management and planning project and the success of project depends upon the accuracy in prioritization at large extent. In developing country like India where availability of data is a major constraint, to prepare a fruitful project plan, such morphological parameters based methodology as discussed in this paper has high practical utility. The proposed methodology for prioritization of a catchment using morphological parameters in GIS environment is easy to use and very useful for an un-gauged catchment. Since, most of data used in the study are freely available; the proposed approach is parsimonious in terms of funds and also time saving. Once identify the criticality of these watersheds using morphological based approach would help in facilitating investment decision and making best use of the available resources. The proposed approach is not only fixing the priority but it also quantifies the erosivity, in terms of SPR values, with in the catchment which is also helpful to divide the treatment activities in proportionate to the erosivity. Moreover, it can be helpful to allocate the budget for treatment in different watersheds within the catchment. In the present study, rainfall intensity and volume and its variation within the watershed has not considered, therefore, sediment production rate (SPR) estimated for different subwatersheds of Ujh catchment cannot be compared quantitatively with the sediment yield data at the watershed outlet.

\section{References:}

1) Agarwal, C. S., Chakraborty, B. (1994). Morphometric Analysis in part of Mussoorie Syncline, Hydrology Journal, XVIII, (1\&2), 54-57.

2) Aksoy, H., and Kavvas, M.L., (2005). A review of hillslope and watershed scale erosion and sediment transport models. Catena, 64, 247-271.

3) Apaydin, H., Ozturk, F., Merdun, H. \& Aziz, N.M., "Determination of the drainage basin characteristics using vector GIS"NordicHydrol.37(2),129142(2006).

4) Anbazhagan S, Ramasamy SM (2005) Evaluation of areas for artificial groundwater recharge in Ayyar basin, Tamil Nadu, India through statistical terrain

5) Beasley, D.B., Huggins L.F., and Monke, E.J. (1980). ANSWERS - a model for watershed planning. Transactions of American Society of agricultural Engineers, 23: 938-944.

6) Choudhary, R. S. and Sharma, P.D. (1998). Erosion hazard assessment and treatment prioritization of Giri river catchment; north-western Himalaya. Indian J. Soil Cons., 26(1), 6-11.

7) Dillaha, T.A., Wolfe, M.L., Shirmohammadi, A., and Byne, F.W. (2001). ANSWERS-2000. In: Parsons, J.E., Thomas, D.L., Huffman, R.L. (Eds.), Non-Point Source Water Quality Models: Their Use and Application. Final Report of USDA-CSREES Southern Region Research Project S-273, Development and Application of Comprehensive Agricultural Ecosystems Models, $200 \mathrm{pp}$.

8) Elwell, and H.A. (1978). Modelling soil losses in southern Africa. Journal of Agricultural Engineering Research, 23: 117-127.

9) Ferro, V., and Porto, P. (2000). A sediment delivery distributed (SEDD) model. J. HydrolEngng ASCE, 5(4), 411-422.

10) Foster, G.R., Lane, L.J., Nowlin, J.D., Laflen, J.M., and Young, R.A. (1981). Estimating erosion and sediment yield on field-sized areas. Transactions of the ASAE, pp. 1253-1262.

11) Garen, G., Woodward, D., and Geter, F. (1999). A user agency's view of hydrologic, soil erosion and water quality modelling. Catena, 37: 277-289.

12) Ghayoumian J, Ghermezcheshme B, Feiznia S, Noroozi AA (2005) Integrating GIS and DSS for identification of suitable areas for artificial recharge, case study, Meimeh Basin, Isfahan, Iran. Environ Geol 47(4):493-500

13) Goel, A. K. (2003). Geo-morphological studies in Soan river catchment in north-west Himalayas of India. Indian J. Soil Cons., 31(2), 120-126. 


\section{International Journal of Advanced Multidisciplinary Scientific Research (IJAMSR) ISSN:2581-4281}

14) S. Grauso, G. Fattoruso, C. Crocetti, A. Montanari. Estimating the suspended sediment yield in a river network by means of geomorphic parameters and regression relationships. Hydrology and Earth System Sciences Discussions, European Geosciences Union, 2008, 12 (1), pp.177-191.

15) Gupta, V.K., Waymire, E., and Wang, C. T. (1980). A representation of an instantaneous unit hydrograph from geomorphology. Water Resour. Res., 16(5), $863-870$,

16) Hack, J.T. (1973) Stream-Profiles Analysis and Stream-Gradient Index. Journal of Research of the U.S. Geological Survey, 1, 421-429

17) Horton R.E. (1945).Erosion development of streams and their drainage basins; hydrophysical approach to quantitative morphology. Geological Society of America Bulletin, 56(3): 275

18) Jaiswal, R. K. and Krishnamurthy, J. (2007). Role of landform and topography in the development of drainage network Hydrology Journal, 30(1-2), 1-13.

19) Nag S. K. and Chakroborty S., Influence of rock types and structures in the development of drainage networks in hard rock area, J. Ind. Soc., Rem. Sens., 31(1), 25-35, (2003).

20) Nooka Ratnam, K. (2005). Check dam positioning by prioritization of micro-watershed using SYI model and morphometric analysis-Remote sensing and GIS perspective. J. of the Indian Soc. of Remote Sensing, 30(1), 39-61.

21) Ozdemir, H. and Bird, D. (2009) Evaluation of morphometric parameters of drainage networks derived from topographic maps and DEM in point of floods, Envi. Geol. 56: 1405 - 1415.

22) Pakhmode, V., Kulkarni, H., and Deolankar, S.B (2003): Hydrological drainage analysis in watershed programme planning: A case study from the Deccan basalt, India. Hydrogeology Journal, 11:595 - 604.

23) Patton, P. C. (1988) Drainage basin morphometry and floods, In: Baker, V. R., Kochel, R. C., Patton, P. C. (Eds), Flood geomorphology, Wiley, USA, pp 5165

24) Rawat SS, Kumar P and Jose PG (2016) Assessment of Areas Vulnerable to Soil Erosion and Deposition in a Himalayan Watershed. Indian J Eco (43): 2833.

25) Reddy, G. P. O., Maji, A. K. and Gajbhiye, K. S. (2004). Drainage morphometry and its influence on landform characteristics in a basaltic terrain, Central India - a remote sensing and GIS approach. International Journal of Applied Earth Observation and Geoinformation, 6, 1-16.

26) Rodriguez-Iturbe, I., and Valdés, J.B. (1979). The geomorphologic structure of the hydrologic response, Water Resour. Res., 15(6), 1409-1420.

27) Rymbai $P N$ and Jha, $L K$. (2012) estimation of sediment production rate of the Umbanium Microwatershed, Meghalaya, Indai. Journal og geography and regional planning, Vol. 5(11), pp293-297.

28) Schumm SA (1956) Evolution of drainage systems and slopes in badlands at Perth Amboy,
29) New Jersey. Geol Soc Am Bull 67:597-646

30) Schumm SA (1963) Sinuosity of alluvial rivers in the great plains.Bull Geol Soc Am

31) 74:1089-1100

32) Smith, R.E. (1981). A kinematic model for surface mine sediment yield. Transactions of the ASAE, 1508-1514.

33) Strahler A.N. (1964). Quantitative geomorphology of drainage basins and channel networks. Section 4-11 in Handbook of Applied hydrology(Ed. By V. T. Chow), Mc Graw Hill , New York.

34) Strahler, A. N. (1957). Statistical analysis in geomorphic research. J Geol 62, 1-25.

35) Williams, J.R. (1975). Sediment routing for agricultural watersheds. Wat. Resources, Bull. 11, 965-974.

36) Zernitz, E.R. (1932) Drainage Patterns and Their Significance. Journal of Geology, 40, 498521. http://dx.doi.org/10.1086/623976 